\title{
Corruption Phenomenon In European Union
}

\author{
Laura-Maria Popescu, Silviu Duțulescu, and Ileana Nișulescu-Ashrafzadeh
}

\begin{abstract}
The article presents the consequences and dimension of corruption phenomenon on level of $\mathrm{EU}$ countries in the year 2013. Based on the data collected from the reports of the World Bank, the reports of United Nations and Transparency International, it has been performed an econometric adjustment using as dependent variable the index of perception of the corruption on level of EU countries, plus 5 independent variables as follows: trust in public institutions, trust in justice, trust in government, freedom of expression and HDI (human development index). Pursuant to multiple regression and several calculations, it has been elaborated a classification of the countries of European Union relying on an estimate of corruption phenomenon based on such variables. The classification obtained has been divided in 3 subdivisions (green area, orange area and red area) depending on the scores recorded in each country, being performed subsequently analyses, comparisons, correlations related to the position of each country in the classification as well as the identification and analysis of the factors influencing the dimension of corruption phenomenon in such countries. The information obtained pursuant to analyses has been synthesized and represented in the form of a chart and a map presenting briefly the entire scientific demarche.
\end{abstract}

Index Terms-Corruption, European Union, Anticorruption Fight, Classification of Countries, Maps.

\section{INTRODUCTION}

Corruption represents one of the biggest threats for the democratic ideal of self-government, by breaching social justice, by disparagement of state institutions and undermining of economic development (Strapenhurst et al, 2006). The corruption phenomenon may be defined as a mechanism by which public services are used on purpose to obtain personal gains (Jensen et al., 2010). The experiences of past years have shown that such phenomenon has a transnational nature, and there is a rather strong connection between corruption and the other forms of criminality. In this context, the world governments have reacted and started to adopt different measures to prevent and combat corruption. In December 2000, the General Meeting of UN submitted an invitation to all states to elaborate an international legal instrument of fight against corruption (Resolution 55/61). Such instrument entailed the determination of a high standard of measures on increase of efficacy and efficiency in preventing and combatting corruption. It entailed as well detailed measures for the prevention of corruption, by enforcing policies and practices of prevention and codes of conduct to public officers. The

Published on July 19, 2019

Authors are with the Academy of Economic Studies, Bucharest, Romania.

JEL classification: C51, D03, M48, O17 final objective was criminal investigation of corruption actions, as well as seizure, forfeit and recovery of damages caused. This initiative was materialised by conference organised between $9^{\text {th }}-11^{\text {th }}$ December 2003 organised in Merida (Mexico) when opened for signing the Convention of Unites Nations against corruption. Perceiving the importance of this demarche of Unites Nations in the anticorruption process, on $15^{\text {th }}$ September 2005 the European Commission and the presidency of the Council signed the Convention on the name of European Community.

The anticorruption fight is a very important element for the economic health of any state. Corruption may significantly reduce the investments and determines the companies to adjust to the economic environment, however the companies may form partnerships with some internal companies to protect against corrupted politicians (Ionescu, Lăzăroiu and Gheorghe, 2012). Press freedom represents a significant hint of the perception of companies concerning the dimension of corruption phenomenon, which may endanger their business in progress. From this perspective, in the country where press freedom is almost absent, there is a trend of under-evaluation of the dimension and depth of corruption phenomenon, and people are made believe that this phenomenon is almost inexistent (Jensen et al., 2010).

Widely, we may talk about corruption in the private environment as well, where exploited opportunistically the same tension present as well in the governance of all organisations. The difference is that non-coercive arrangements have (if not narrowed artificially by third/public ruling) more space of operation in discouraging such deviations, through the contracts concluded expressly or mechanisms like: reputation, competition and cooperation in and between the organizations (Marinescu and Jora, 2013).

From the economic perspective, corruption may be perceived as a phenomenon having as result a financial loss in over $90 \%$ of cases. This philosophy is supported as well by anticorruption report of EU, dated February 2014, issued by the European Commission, the conclusions being that annually the EU member states UE incur losses of approximately 120 billion euro. The main factors favouring the development and maintenance of corruption are poverty, political instability, bureaucracy, collective mentality of people, education, greed and mistrust of people in public institutions.

In 2000, Romania participated to the Initiative of Combatting Corruption in the south-east of Europe, within the stability pact (SPAI), having as objective helping and supporting the countries in the area to adopt laws, to create institutions and to stimulate civil society in anticorruption 
fight (Giurgiu, Stroe and Luca, 2000). Pursuant to adhesion to European Union, to the reforms and implementation of European directives, Romania has sustained a constant fight to combat corruption. Despite all these, the frequency of bribes within local public authorities is perceived as very high. The corruption phenomenon, on the territory of Romania is distributed on two directions, therefore, we have the „big corruption” and the „small corruption”. Whereas the ,, big corruption" is specific to managing positions, with serious forms of fraud, funds` extortions and even forms of organised criminality, is punished much more severely, since economic benefits are significant and focus on a lower number of individuals, the ,small corruption” represents the target of preventive actions attacking the base of phenomenon pyramid (Micu and Nica, 2013), tending to generalize in a normal state of fact, being determined by social inequalities and inequities.

An incorrect legal system, which favours inequities and fails to impose transparency within a society, represents a catalyser in the development of corruption phenomenon. A study on this topic (Uslaner, 2008), shows how countries with more authoritarian regimes are much more predisposed to develop a high corruption degree on higher levels. Focusing on public institutions, where the level of corruption phenomenon is on high levels, we may encounter two different types of individuals with different views on corruption. Among officers, we have both men and women who are supporting corrupted conducts, however, understanding the motivations on which relies each category may help us to reduce the corrupted conduct in the public institutions (Mihăilă, 2011). According to Alolo, the womanized traits such as pity and compassion support the justifications of female officials for corruption, whereas the male traits such as objectivity and money point out the justifications of male officials for supporting corruption. Last but not least, the conducts supporting the corruption phenomenon must be discouraged and even sanctioned, regardless if they involve men or women, however, the understanding of such conducts could help us in solving such states of fact, much easier and with lower costs.

Heckelman and Powell area analysing the correlation between the phenomenon of corruption and economic development of a country in the context when both public institutions and companies in the private environment are contaminated by the corruption phenomenon.

The corruption phenomenon is closely connected to the accounting activity of institutions and companies, by leading to extreme the manipulation practices of financial statements.

In order to interfere in the activity of an enterprise, corruption takes the form of financial-accounting engineering or fraud, elements having always a motivation base. No matter if we refer to the will of obtaining financial resources, contractual facilities, avoidance of payments, maintenance of market position or attraction of new investors, it is important to know that its enforcement always depends on the restrictions applied to companies by the users of financial-accounting statements. The main determining factors for occurrence of manipulations in bookkeeping are schematically presented in Fig. 1.

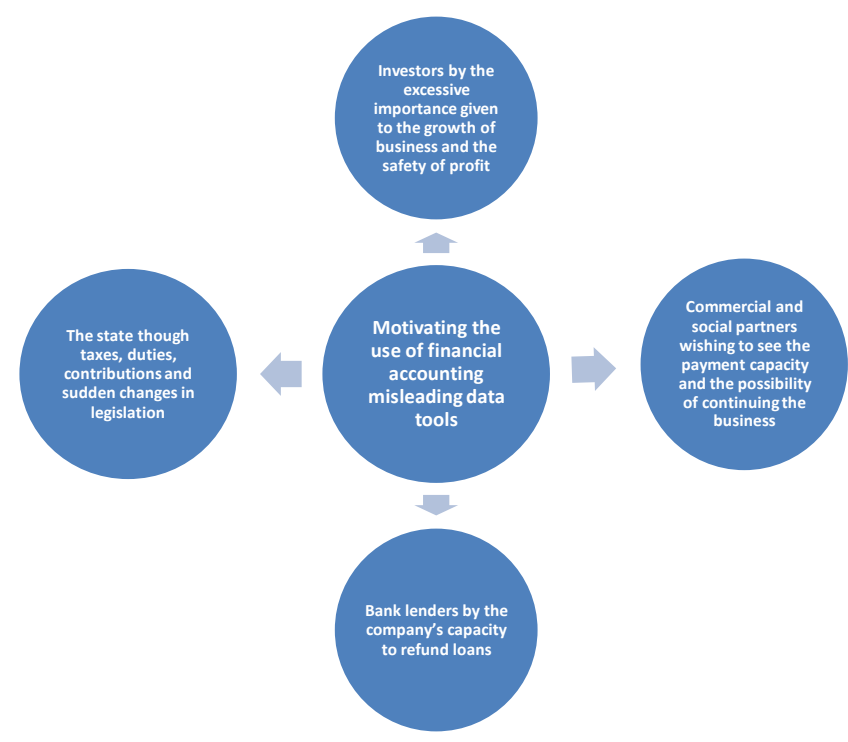

Fig. 1. Motivation for using financial-accounting engineering as corruption element

The idea of accounting engineering is current among companies, therefore, corruption is reduced as the democracy increases and increases when economic freedom decreases (Păun, 2011). The reasoning is that when a state becomes increasingly democratic, the main social values (equality, freedom of expression, trust in state institutions) tend to inhibit the development of corruption phenomenon, and as the economic freedom decreases and pressure is put on it, a potential release may be represented by the attempt to breach the rules of society and thus the corruption phenomenon gains ground. Moris analyses the conditions which may influence the capacity of political elite to institute reforms in order to reduce corruption, the capacity of different actors to promote and implement anticorruption measures, and the forces undermining such efforts (Moris, 2009). Therefore, we may assert that democracy may significantly reduce the level of corruption, whereas corruption has the potential to undermine democracy, and when a country adopts increasingly the democratic values, creates premises on long term for a reduced level of corruption, whereas a state recording high values related to the corruption phenomenon finds it difficult to tend to a strong democrat system.

\section{Methodology}

Studies related to corruption on macroeconomic level are performed by different entities, however, one of the most representative and internationally known becoming also an important supplier of data in this scientific demarche, is Transparency International, which is studying the perception of corruption phenomenon in the majority of the countries of the world. The article has as objective the elaboration of a classification based on which a map will be drafted, and the novelty element related to other similar studies is given by the fact that this classification will rely on estimates concerning the dimension of corruption phenomenon. Information about 5 main causes of corruption phenomenon has been collected which may be evaluated and quantified properly.

These are: trust in public institutions, trust in justice, trust 
in government, freedom of expression and HDI (human development index), and the sources of such information are the reports of United Nations respectively the reports of World Bank. The 5 variables (causes) will be reported to a system of reference represented by the Index of perception of corruption calculated by Transparency International.

For the year 2013 it is performed a multiple regression using the statistic soft Eviews. Firstly, it is tested the validity of significance of coefficients according to the 2 work hypotheses:

$\mathrm{H}_{0}: \beta_{\mathrm{i}}=0$ (it is not statistically important)

$\mathrm{H}_{1}: \beta_{\mathrm{i}} \neq 0$ it is statistically important)

where:

$\mathrm{i}=1,2$ and $\beta-$ slope of regression line

The significance level is of $5 \%$, and in order to exclude a false regression, the value of $\mathrm{R}^{2}$ coefficient is compared with the values of Durbin Watson statistics. In order to investigate the correlation of residuals it is used Breuch Godfrey test for a number of 2 lags, with the following hypotheses to test:

\section{$\mathrm{H}_{0}$ : There is no self-correlation \\ $\mathrm{H}_{1}$ : There is self-correlation}

In order to check whether the residuals are homoscedastic, that is if they have constant variance it is used White test, which relies on the regression of residuals squares in relation to exogenous variables, with its squares and crossed products. The hypotheses tested are:
$\mathrm{H}_{0 \text { : }}$ The model is homoscedastic (There is no heteroscedasticity)
$\mathrm{H}_{1}$ : The model is not homoscedastic (There is heteroscedasticity
)

In order to determine if the residuals follow or not a normal distribution, it was deemed proper the use of JarqueBera test. The hypotheses tested are:

$\mathrm{H}_{0}$ : The residuals are normally distributed

$\mathrm{H}_{1}$ : The residuals are not normally distributed

The values of correlation coefficients are applied to the 5 independent variables, and pursuant to the elaboration of database and all calculations, based on a score, it is elaborated a classification of all states in decreasing order. The first 9 countries with the highest scores are the countries with the estimate of the lowest level of corruption on level of European Union and are marked on map by green, the next 9 by orange, these are countries with moderate level of corruption phenomenon, and the last 9 countries at the end of classification are marked by red, meaning that the level of corruption in these countries is on high levels, over the average of European Union countries. Based on such information, different observations, comparisons, opinions, personal considerations and even predictions are formulated for the next years.

\section{RESULTS OF SEARCH}

The scope of this search is to provide a fast instrument and easy to interpret to a potential investor who wants to develop a business on the territory of European Union, considering that one of the highest obstacles is time, and this time waste may entail for it a loss of money. This work has as scope to draft actually a map of the countries of European Union, in the light of corruption phenomenon, which most of the times does not suggest difficulties only to investors but to the entire population of a country, including to leading governments. It was decided to elaborate a classification and a map for the year 2013, with a view to create different (optimistic / pessimistic) scenarios related to future evolution. The population subject to analysis is represented by the current member states of European Union excluding Malta, due to insufficient data collected about it.

Pursuant to applying the regression model for the year 2013, the following outputs were obtained:

\begin{tabular}{|c|c|c|c|c|}
\hline INSTITUTII_PUBLICE & 0.698389 & 0.284459 & 2.455149 & 0.0229 \\
\hline JUSTITIE & 0.018122 & 0.278857 & 0.064985 & 0.0488 \\
\hline GUVERN & 0.706690 & 0.282181 & 2.504385 & 0.0206 \\
\hline LIBERTATE_EXPRIMARE & -0.069102 & 0.344647 & -0.200502 & 0.0130 \\
\hline HDI & -4.942202 & 27.44374 & -0.180085 & 0.0358 \\
\hline $\mathrm{c}$ & -44.28549 & 25.98069 & -1.704554 & 0.1030 \\
\hline R-squared & 0.915532 & & dentvar & 63.55556 \\
\hline Adjusted R-squared & 0.895421 & & & 15.63855 \\
\hline S.E. of regression & 5.057304 & Akaike infoc & riterion & 6.272674 \\
\hline Sum squared resid & 537.1027 & Schwarz crit & & 6.560638 \\
\hline Log likelihood & -78.68110 & F-statistic & & 45.52308 \\
\hline Durbin-Watson stat & 1986684 & Prob(F-statis & & 0,000000 \\
\hline
\end{tabular}

Fig. 2. Multiple regression 2013

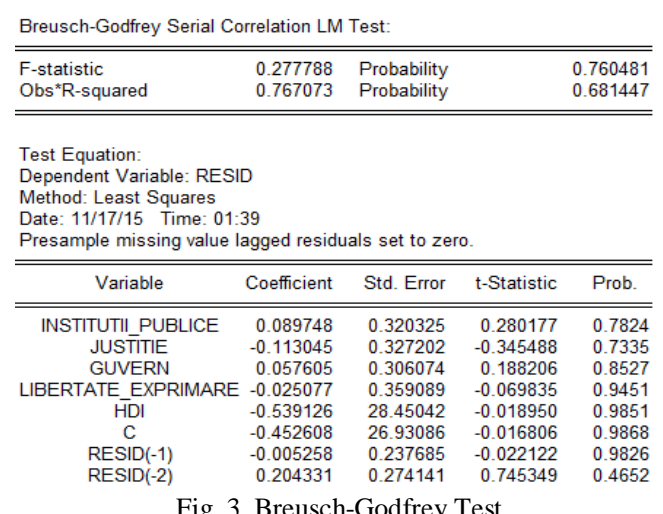

It is noticed that the probabilities of the coefficients estimated are under $5 \%$, therefore, it may be asserted with a probability of $95 \%$ that such coefficients are significantly statistic. Also, it is noticed that the value of $\mathrm{R}^{2}$ coefficient is under the value of Durbin-Watson statistics, which excludes the possibility of a false regression. We notice that the 5 variables exercise an influence over the corruption phenomenon in proportion of $91.55 \%$. For investigation related to self-correlation of residuals, it was used BreuchGodfrey test. Whereas the probabilities afferent to statistics of test are over the level of 5\% it is accepted null hypothesis, meaning that residuals are not affected by self-correlation. 
White Heteroskedasticity Test:

\begin{tabular}{|c|c|c|c|c|}
\hline $\begin{array}{l}\text { F-statistic } \\
\text { Obs }{ }^{\star} R \text {-squared }\end{array}$ & $\begin{array}{l}0.988713 \\
10.31217\end{array}$ & $\begin{array}{l}\text { Probability } \\
\text { Probability }\end{array}$ & & $\begin{array}{l}0.490104 \\
0.413545\end{array}$ \\
\hline \multicolumn{5}{|l|}{$\begin{array}{l}\text { Test Equation: } \\
\text { Dependent Variable: RESID } 2 \\
\text { Method: Least Squares } \\
\text { Date: } 11 / 17 / 15 \text { Time: } 01: 41 \\
\text { Sample: } 127 \\
\text { Included observations: } 27\end{array}$} \\
\hline Variable & Coefficient & Std. Error & t-Statistic & Prob. \\
\hline $\mathrm{C}$ & -2248.901 & 2796.774 & -0.804105 & 0.4331 \\
\hline INSTITUTII_PUBLICE & -7.501311 & 10.27023 & -0.730394 & 0.4757 \\
\hline INSTITUTII_PUBLICE^2 2 & 0.032288 & 0.065853 & 0.490297 & 0.6306 \\
\hline JUSTITIE & -6.599228 & 12.58778 & -0.524257 & 0.6073 \\
\hline JUSTITIE^2 & 0.060233 & 0.086214 & 0.698645 & 0.4948 \\
\hline GUVERN & 15.72855 & 17.26378 & 0.911072 & 0.3758 \\
\hline GUVERN^2 & -0.100490 & 0.105435 & -0.953096 & 0.3547 \\
\hline LIBERTATE EXPRIMARE & 0.906871 & 17.62958 & 0.051440 & 0.9596 \\
\hline LIBERTATE_EXPRIMARE^2 & -0.009865 & 0.115180 & -0.085652 & 0.9328 \\
\hline $\mathrm{HDI}$ & 5160.132 & 6598.406 & 0.782027 & 0.4456 \\
\hline $\mathrm{HDI} 2$ & -3047.783 & 3891.294 & -0.783231 & 0.4449 \\
\hline
\end{tabular}

Fig. 4. White Heteroskedasticity Test

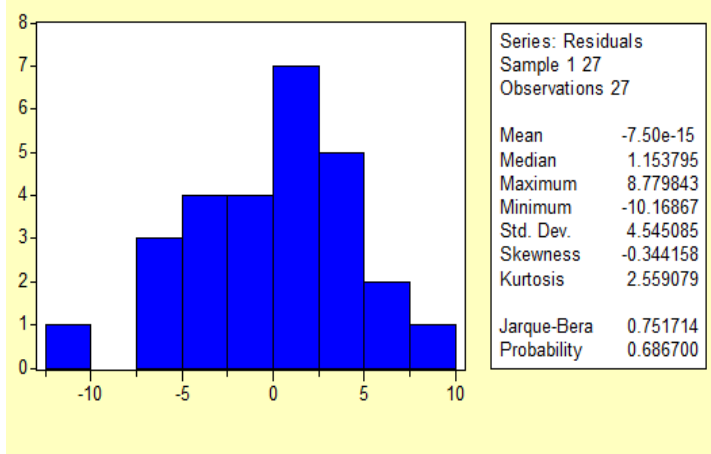

Fig. 5. Jarque-Bera Test

In order to check the homoscedasticity of residuals, that is whether they have a constant variance, White test will be used. It is noticed that the probabilities afferent to $\mathrm{F}$ statistics are over the level of $5 \%$, therefore, it is accepted null hypothesis, thus the residuals are homoscedastic. For the last test, Jarque-Bera which determines whether the residuals follow or not a normal distribution it is noticed that the probabilities afferent to Jarque-Bera statistics are over the level of $5 \%(0,68>0,05)$, therefore, it is accepted null hypothesis, thus the residuals are normally distributed. Whereas the hypotheses of model are observed and the coefficients are significant, we may draw the conclusion that there is a correlation between the corruption phenomenon and the 5 variables which will be submitted to a detailed analysis.

TABLE I: CLASSIFICATION OF COUNTRIES DEPENDING ON PERCEPTION OF CORRUPTION

\begin{tabular}{|c|c|c|c|c|c|c|c|}
\hline No crt & County & $\begin{array}{l}\text { Perception of } \\
\text { corruption } \\
\text { phenomenon }\end{array}$ & $\begin{array}{l}\text { Trust in public } \\
\text { institutions }\end{array}$ & Trust in justice & $\begin{array}{c}\text { Trust in } \\
\text { government }\end{array}$ & $\begin{array}{l}\text { Freedom of } \\
\text { expression }\end{array}$ & HDI \\
\hline 1 & Denmark & 9,4 & 99,05 & 99,06 & 99,53 & 98,12 & 0,899 \\
\hline 2 & Finland & 9,4 & 100,00 & 100,00 & 97,63 & 96,24 & 0,879 \\
\hline 3 & Sweden & 9,3 & 98,58 & 99,53 & 99,05 & 99,53 & 0,896 \\
\hline 4 & Netherlands & 8,9 & 96,68 & 97,65 & 97,16 & 97,18 & 0,914 \\
\hline 5 & Luxemburg & 8,5 & 95,26 & 96,71 & 98,58 & 97,65 & 0,881 \\
\hline 6 & Germania & 8,0 & 91,47 & 91,55 & 92,89 & 93,43 & 0,908 \\
\hline 7 & Anglia & 7,8 & 91,94 & 82,49 & 95,26 & 92,02 & 0,891 \\
\hline 8 & Austria & 7,8 & 93,36 & 97,18 & 90,52 & 94,84 & 0,879 \\
\hline 9 & Belgium & 7,5 & 93,84 & 89,20 & 86,73 & 92,96 & 0,880 \\
\hline 10 & Ireland & 7,5 & 88,63 & 96,24 & 93,36 & 92,49 & 0,900 \\
\hline 11 & France & 7,0 & 87,68 & 90,14 & 84,36 & 87,32 & 0,882 \\
\hline 12 & Estonia & 6,4 & 82,46 & 85,45 & 91,00 & 85,92 & 0,836 \\
\hline 13 & Cyprus & 6,3 & 92,42 & 83,57 & 86,26 & 81,69 & 0,850 \\
\hline 14 & Spain & 6,2 & 81,52 & 85,92 & 81,52 & 82,63 & 0,868 \\
\hline 15 & Portugal & 6,1 & 78,20 & 81,69 & 73,46 & 84,04 & 0,819 \\
\hline 16 & Slovenia & 5,9 & 80,57 & 82,16 & 74,88 & 81,22 & 0,874 \\
\hline 17 & Poland & 5,5 & 71,56 & 72,30 & 78,20 & 77,93 & 0,830 \\
\hline 18 & Lithuania & 4,8 & 72,99 & 73,24 & 78,67 & 73,71 & 0,828 \\
\hline 19 & Hungary & 4,6 & 72,04 & 71,36 & 81,04 & 74,18 & 0,817 \\
\hline 20 & Czech & 4,4 & 77,73 & 80,75 & 85,31 & 77,00 & 0,861 \\
\hline 21 & Latvia & 4,2 & 72,51 & 71,83 & 79,15 & 69,01 & 0,804 \\
\hline 22 & Croatia & 4,0 & 70,14 & 60,56 & 70,14 & 62,91 & 0,812 \\
\hline 23 & Slovakia & 4,0 & 75,83 & 67,61 & 80,09 & 76,06 & 0,827 \\
\hline 24 & Italy & 3,9 & 65,88 & 62,91 & 75,36 & 75,12 & 0,872 \\
\hline 25 & Romania & 3,6 & 44,55 & 56,81 & 74,41 & 58,69 & 0,782 \\
\hline 26 & Greece & 3,4 & 68,25 & 67,14 & 68,72 & 70,89 & 0,854 \\
\hline 27 & Bulgaria & 3,3 & 60,19 & 50,70 & 70,62 & 61,50 & 0,774 \\
\hline
\end{tabular}

Pursuant to applying the regression model, it has been elaborated a classification related to the position of EU countries depending on estimating the dimension of corruption phenomenon, presented in Table II. The score obtained by each country has been calculated by application of correlation coefficients on the 5 independent variables, and as the score obtained by a country is higher the level of corruption is lower. 
TABLE II: CLASSIFICATION OF COUNTRIES DEPENDING ON ESTIMATE OF CORRUPTION PHENOMENON

\begin{tabular}{lclcll}
\hline \hline \multicolumn{1}{c}{ Country } & Score & Country & Score & Country & Score \\
\hline Sweden & 128,21 & Belgium & 113,51 & Slovakia & 88,72 \\
\hline Denmark & 126,74 & Estonia & 108,91 & Hungary & 88,62 \\
\hline Luxemburg & 125,89 & France & 106,33 & Lithuania & 87,04 \\
\hline Finland & 125,59 & Cyprus & 102,05 & Latvia & 83,56 \\
\hline Netherlands & 123,14 & Spain & 99,37 & Italy & 80,50 \\
\hline Austria & 119,49 & Portugal & 98,59 & Greece & 75,82 \\
\hline Ireland & 116,38 & Czech & 93,98 & Croatia & 69,31 \\
\hline Germany & 115,51 & Slovenia & 93,36 & Bulgaria & 66,60 \\
\hline England & 113,60 & Poland & 90,52 & Romania & 65,29 \\
\hline \hline
\end{tabular}

We have a number of 27 countries which, from the perspective of perception of corruption phenomenon, we may divide in 3 classes. The first class includes the countries that have accumulated the highest scores ranging between 7,5-9,4 (Denmark, Finland, Sweden, Netherlands, Luxemburg, Germany, England, Austria, and Belgium). From the perspective of estimating the corruption phenomenon, the differences are rather low, which means that the perception of population related to the dimension of corruption phenomenon was rather realistic. The sole country where the optimism feeling is slightly higher is Belgium, which, although on the last position of green area, descended on the first position of orange area according to the classification of estimating the corruption phenomenon, whereas Ireland from $10^{\text {th }}$ position reached to $7^{\text {th }}$ position, entering directly in the green area. This may be due to a complex of factors such as strong economic potential, low level of corruption and providing a high living level among population, therefore any potential deviation (of public officers, mass-media, political class, etc) is punished and sanctioned by public opinion and even by competent institutions, if any. The average of score related to perception of corruption phenomenon for the first classification is of 8,51 points, $23,23 \%$ higher than the average of the second class of countries including Ireland, France, Estonia, Cyprus, Spain, Portugal, Slovenia, Poland and Lithuania. For the countries from class 2, the average score is of 6,18 points, representing a decrease by $37,54 \%$ opposite to the first 9 countries. For the second class, the differences between the level of perception of corruption phenomenon and the estimate of corruption phenomenon, are less obvious. Latvia, where the feeling of corruption on level of public opinion is rather optimistic, according to estimates, reaches directly the red area on position 21 of classification. Czech, according to the perception of corruption phenomenon was in the red area occupying position 22, but it reaches the orange area with a score of 93,98 points. For the last class of countries, the differences in terms of perception respectively the estimate of corruption phenomenon are maintained constant as in case of the second class. According to our classification, Czech was ascended and left the red area whereas Lithuania has just left the orange area and has been included in the category of countries with a high level of corruption phenomenon. The first conclusions show that as we approach the red area the differences between perception and estimate of corruption phenomenon start to be emphasised more clearly. If we analyse the first and last position, we notice again a difference between the 2 classifications, but, unfortunately, such countries are part of the same class, although their position in the classification is different.

Based on the data from Table II it was performed the distribution of classes, and accordingly it has been drafted a map with the situation of classification of countries analysed for the year 2013 .

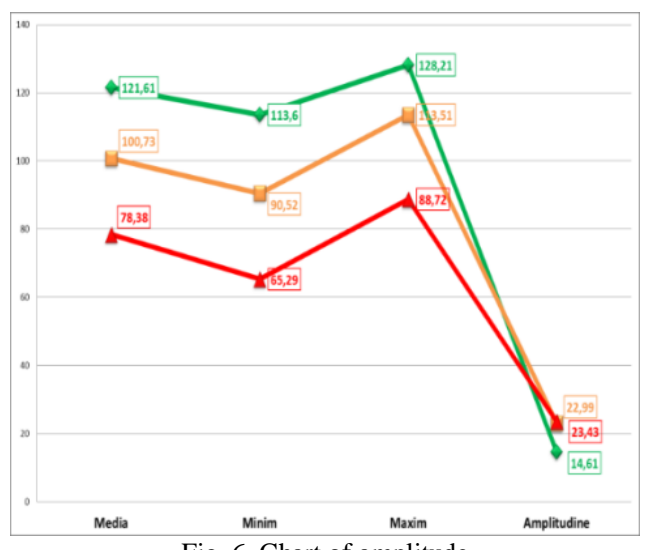

Fig. 6. Chart of amplitude

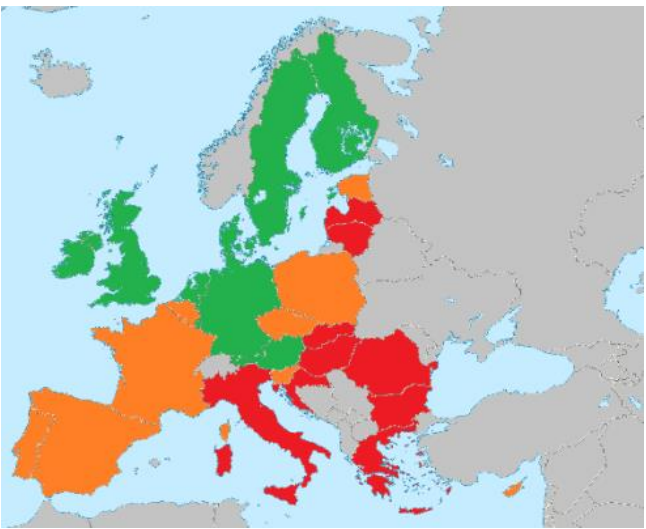

Fig. 7. Map of corruption in EU

In chart 5 the 3 classes of countries are presented being classified depending on the estimate of corruption phenomenon. For a better exemplification we have attached a coloured map in the same colours indicating exactly the countries afferent to each class. For the countries in the green area, we record the highest average of score of 121,61 points, overcoming event the highest score recorded by the first country from class 2 (Belgium 113,51). For minimum and maximum scores afferent to the countries from the three classes, the variations are rather symmetric, we encounter a small exception on maximum values of first and $2^{\text {nd }}$ class of only 14,7 points opposite to 24,79 points recorded for classes 2 and 3. Significant differences are encountered when evaluating the variation of scores related to the estimate of corruption phenomenon in the 3 classes. It is noticed how for the first class the difference between the country with the highest score (Sweden 128,21) and the country with the lowest score (Anglia 113,60) is of only 14,61 points whereas for classes 2 and 3 the amplitudes are over 22,99 respectively 23,43 points.

\section{CONCLUSIONS}

There are two main reasons that determine a person to commit corruption acts, namely greed, situation almost impossible to quantify since, in the absence of measurable 
information, it cannot be evaluated the appetite for the wish of fast enriching of population in a particular country, and the second reason is represented by the mix of causes submitted to a thorough analysis in this search. This is also added the collective mentality of population related to the approach of corruption phenomenon, as well as customs of receiving and giving, tolerated worldwide.

It was noticed a correlation between the living level in a country and the perception of population related to the dimension of corruption phenomenon, which are surprisingly correlated to the level of economic development of such country, the people acting without being aware of the risks undertaken when they participate to corruption acts.

The economic potential of a country has a very important role, the government of a country being able to invest more in the wellbeing of population, which reduces the corruption phenomenon opposite to a country like Bulgaria or Romania, facing major difficulties in this respect. This hypothesis is proved by the data on which such search relies. We have countries with high economic development like Denmark, Finland, Sweden, Luxemburg, where both the perception of corruption phenomenon of International bodies and the estimate of corruption phenomenon in this study show exactly this correlation between the economic potential and the level of corruption.

Among the causes of non-ethical conduct one may state the gain and temptation exercised on the persons involved in the corruption phenomenon, mainly if the motivational awards are low or are absent, competition, both on market in relation with the other companies and within it, among employees, and the personality of managers by moral and ethical limits, who want to succeed by economic value and power.

The corruption practices will disappear only with the disappearance of causes generating it, therefore, the wish of accounting normalizers to restrict creative bookkeeping must consider the circumstances that allow the manifestation of it. However, experience shows that, every time a new norm appears, the entities find a way to reduce its impact. Therefore, no matter the number of rules governing a profession, there will always be individuals that find a way to "defeat" the system. Consequently, the mission of accounting normalizers and professionals is not simple: imagination must be answered with imagination.

The map drafted pursuant to the search synthesises the entire scientific demarche and it is useful for a better understanding of the evolution of corruption phenomenon on level of European Union countries, and of the evolution of this phenomenon in the next years.

Low values of corruption phenomenon were recorded in the area of Scandinavian countries, in Central Europe and in England and Ireland., and the highest values concerning the corruption phenomenon were recorded in the south-east countries of Europe, which are maintained every year in the red area. In countries like Romania, Bulgaria, Greece, Italy and Hungary the effects of financial crisis were visible, being situated during the years subject to analysis in the red area, facing difficulties related to economic relaunch.

The only country of European Union which manages to maintain a maximum score of 100 points for variables as trust in public institutions or trust in justice is Finland, and very high values of over 98 points were also recorded for Sweden.

The main reason that determines a country to pass from one class to other is usually represented by significant variations of the variable trust in government.

An important step in the fight against corruption was made by European Union in September 2005 when it signed the Convention of United Nations against corruption, however, in February 2014, the anticorruption report issued by the European Commission indicated that EU member states are annually losing 120 billion EUR due to the phenomenon of corruption in the entire European Union.

The phenomenon of corruption in the entire European Union is very difficult to control and destroy completely, regardless the efforts in this respect, since there are economic, politic, social, cultural, etc. connections between EU member states and the other countries worldwide. As long as there are economic connections with states like Russia, with one of the highest corruption level on globe, an efficient solution could be the collective effort of all countries of the world to prevent and combat corruption harmonizing international legislations on level of all countries, but as long as the economic, educational, cultural gaps are very high is less probable to be able to implement such initiative.

The final conclusions show that a country with very low level of corruption, must have a strong economy, a high living standard, an average education level of population situated on values over the average of the countries to which we refer and a culture of population directed towards to awareness of risk entailed by the development of corruption phenomenon.

\section{REFERENCES}

Alolo, N.A., 2007. Fighting public sector corruption in Ghana: does gender matter? In: S. Bracking, ed. Corruption and development: the anticorruption campaigns. New York: Palgrave Macmillan, pp.205-220.

EUR-Lex, 2008. Convention of United Nations against corruption. [online] Available at: <http://eur-lex.europa.eu/legalcontent/RO/TXT/?uri=URISERV:133300> [Accessed 2 November 2015].

Giurgiu, A., Stroe, A. și Luca, S., 2002. Corruption in Christian local public administration [online] Available at: < http://www.fdsc.ro/documente/26.pdf $>$ [Accessed 11 November 2015].

Heckelman, J.C. and Powell, B., 2010. Corruption and the institutional environment for growth, Comparative Economic Studies, 52, pp.351378

Ionescu, L., Lăzăroiu, G. and Gheorghe, I., 2012. Corruption and bureaucracy in public services. Economic Amphitheatre, 14(6), pp. 466-479

Jensen, N. et al., 2010. Understanding corruption and firm responses in cross-national firm-level surveys, Journal of International Business Studies, 41, pp.1481-1504

Johnston, R. Pelizzo (eds.), The Role of Parliament in Curbing Corruption. Washington, DC: The World Bank, pp.27-40.

Lederman, D., Loayza, N.V. and Soares, R.R., 2006. On the political nature of corruption, in R. Stapenhurst, N.

Stapenhurst, R., Ulrich, M. and Strohal, S., 2006. Introduction: Parliamentarians fighting corruption, in R. Stapenhurst, N. Johnston and R. Pelizzo (eds.), The role of parliament in curbing corruption. Washington, DC: The World Bank, pp.1-12.

Marinescu, C. and Jora, O., 2013. Assessment on the "institutional economics" of corruption. Business and development in Romania, between formal and informal practices. Economic Amphitheatre, 15(7), pp. $426-438$ 
Micu, G. și Nica, M., 2013. Tax heavens and globalization of corruption. Criminality Investigation Magazine, 4(1), pp. 292-299

Mihăilă, R. 2011. (Un)Gendered private space in nineteenth-century Romanian society, Journal of Research in Gender Studies, 1(1), pp.147-163

Morris, S. D., 2009. Political corruption in Mexico: The impact of democratization. Boulder, CO: Lynne Rienner Publishers

Păun, Ş. 2011. The democratic legitimacy of European governance. Geopolitics, History, and International Relations, 3(2), pp.229-234

Păunescu, B. et al 2012. Study of corruption in Christian local public administration [online] Available at: http://www.portalbn.ro/cj/Lists/Stiri/Attachments/74/RAPORT\% 20COMPREHENSIV.pdf> [Accessed 14 November 2015].

Report of commission to European Council and Parliament. Anticorruption Report of EU [online] Available at: <http://ec.europa.eu/dgs/homeaffairs/e-library/documents/policies/ organized-crime-and-humantrafficking/corruption/docs/acr_2014_ro.pdf> [Accessed November 2015].

Reports aggregate and individual governance indicators for 215 economies over the period 1996-2014, for six dimensions of governance [online] Available at: <http://info.worldbank. org/governance/wgi/index.aspx\#home > [Accessed 25 October 2015].

Signs of time, magazine of Christian analysis and opinion [online] Available at: <http://semneletimpului.ro/international/asia/rusia/rusiaeste-coplesita-de-coruptie.html > [Accessed 9 November 2015].

Transparency International, 2013. Corruption Perception Index 2013. [online] Available at: <http://www.transparency.org.ro/ politici_si_studii// indici/ipc/2013/HartaRezultatelor.pdf> [Accessed 18 October 2015].

Uslaner, E.M., 2008. Corruption, inequality, and the rule of law: The bulging pocket makes the easy life. New York: Cambridge University Press. 